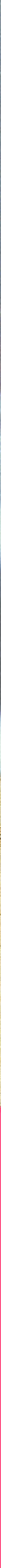




\section{Towards a civilized market economy: economic citizenship rights and responsibilities in service of a bumane society}

PETER ULRICH

\section{A change of perspective: "It's not the economy, stupid - it's society!"}

Everybody remembers Bill Clinton's slogan during his successful 1992 presidential campaign, "It's the economy, stupid!” My premise is that today this motto needs slight modernization. An up-to-date version would be: "It's not the economy, stupid - it's society!"

What is my point? We need to learn to make a clear distinction between economy and society and relate them in a sensible way, instead of confusing the two, as is common practice in neoliberal thinking, with its standard recipe for nearly all socio-economic problems: more market and more competition. The economic logic of competitive markets, productivity, and growth cannot be the whole answer to our societal problems, since these problems are simply a part of the success story of economic "liberalization" and "rationalization." Is it not the inherent purpose of that kind of development to set humans "free" from their workplaces in order to increase labor productivity and economic growth?

One of the core problems today could be that the social organization of our national economies - and of the developing transnational economy - lags behind their steadily rising productivity. What is increasingly needed is an overall reassessment and redesign of the societal relationships between all involved; this could be a prerequisite for an economic development that makes sense with regard to our quality of life. After all, economic activities are not an end in themselves but only a means to "the good life" and the just coexistence of humans in society. The confusion of ends and means also brings about 
a symptomatic confusion of problems and solutions. Precarious labor market conditions are a humane problem for a growing share of the population (jobs near or even beneath the minimum living wage, or even getting a "red card" and being eliminated from the labor market). Nevertheless, this problem is usually alleged to be a necessary part of the systemic solution (whose solution?) to what is considered "economic progress": economic growth. While growth may be qualitative, in the sense of sustainability, it primarily has to be quantitative. Moreover, mainstream economic policy is interested in the development of the gross national product but not in its distribution, because its normative background is rooted in a utilitarian calculus that presumes a precedence of the collective aggregate over individual claims. Obviously, this kind of economic "rationalization" does not include economic reason as a whole. Conventional "pure" economic rationality runs the risk of conflicting with the basic ethical rationality of a well-ordered society of free and equal citizens.

\section{A brief critique of (not quite) pure economic rationality}

One of the core axiomatic elements of the neoclassical concept of economic rationality is that economic agents are strictly concerned with maximizing their own advantage and are mutually unconcerned. No moral obligation influences their interactions. The clever, but onedimensional, homunculus who corresponds to this narrow rationality is called homo oeconomicus. Pure economics develops nothing but the general logic of the success-oriented rational action of individuals only "busy" with the pursuit of their own interests, even in their social relationships beyond the marketplace. Every kind of human interaction and cooperation can be interpreted under the normative logic of mutual advantage. Therefore, pure economics conceives itself as a systematic rationalization perspective for all areas of life and action (economic imperialism).

Modern philosophical ethics develops a completely different normative logic of human interaction as its specific idea of practical reason or ethical rationality (Ulrich 2003, 2008: 13ff.). This idea of ethical rationality develops nothing but the humane grammar of interpersonal relations. Benefit-oriented conditional interaction and cooperation between agents have an economic perspective. Conversely, deontological ethics, or moral philosophy, is exclusively 


\begin{tabular}{|c|c|}
\hline $\begin{array}{l}\text { Economic rationality: } \\
\text { normative logic of } \\
\text { mutual advantage }\end{array}$ & $\begin{array}{l}\text { Ethical reason: } \\
\text { normative logic of } \\
\text { human interaction }\end{array}$ \\
\hline $\begin{array}{c}\text { Power-based } \\
\text { (what can be asserted is what counts) }\end{array}$ & $\begin{array}{c}\text { Justice-based } \\
\text { (what is legitimate is what counts) }\end{array}$ \\
\hline Interest in maximization of private success & Intersubjective moral obligations \\
\hline $\begin{array}{c}\text { Benefit-oriented conditional cooperation } \\
\text { between self-interested, } \\
\text { mutually unconcerned individuals }\end{array}$ & $\begin{array}{l}\text { Unconditional reciprocal respect } \\
\text { and recognition of human beings } \\
\text { as persons of equal dignity }\end{array}$ \\
\hline Market principle & Moral principle \\
\hline
\end{tabular}

Figure 8.1 Ethical reason vs. economic rationality

concerned with the substantiation of interpersonal obligations associated with the unconditional mutual recognition of persons as beings of equal dignity and the resulting reciprocal moral rights and duties: "An attitude which is not integrated in the intersubjective structure of moral demands is not moral at all" (Tugendhat 1994: 64).

Not surprisingly, there is a considerable difference between economic rationality and the ethical idea of reason (Figure 8.1). In the first case, the "given" interests of the individuals already form what is regarded as a sufficient proviso for a rational "balancing of interests" among the participants. In the second case, however, those interests are merely the object of an ethical-critical examination from the viewpoint of their legitimacy under the terms of the moral rights of everyone affected and the protection of those rights. In short, economic rationality is power-based while ethical reason is justice-based. At best, "efficient" market exchange reproduces the "given" power relations. ${ }^{1}$ The market principle of the mutual exchange of benefits can therefore in no way be equated with the moral principle. Instead, the primacy of (political) ethics over market logic is the fundamental economic-ethical principle.

A comprehensive concept of economic reason will include the legitimacy proviso, i.e. the categorical subordination of private benefit or profit seeking to the normative precondition of societal legitimacy.

\footnotetext{
${ }^{1}$ For this fundamental criticism, see Ulrich 2008: $166 \mathrm{ff}$.
} 


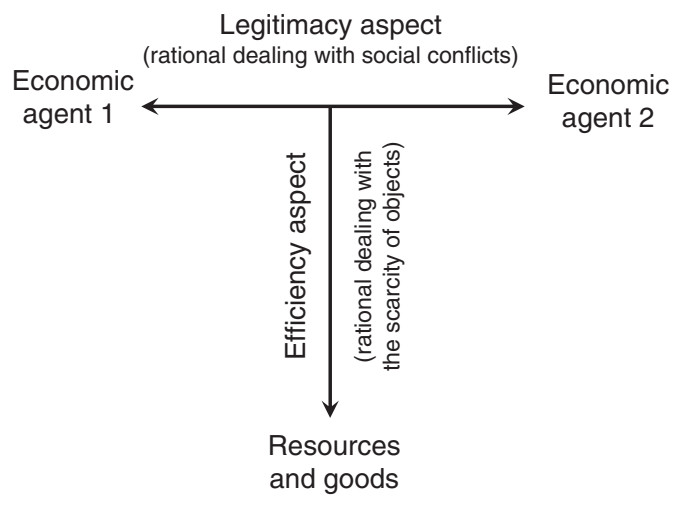

Figure 8.2 The two-dimensional concept of socio-economic rationality

This means that reasonable economic agents will not separate their private business ends from their self-understanding as good citizens. They want or should want to realize only those private benefits that they perceive as justifiable in respect of those concerned. The corresponding regulative integrative idea of socio-economic rationality can be defined as follows: Any action or institution is socio-economically rational which free and mature citizens can - through deliberation between all concerned - consensually justify as a legitimate way of creating value. This integrative idea of reasonable economic activity is the "civilized" perspective of (upright) citizens who regard themselves as persons of integrity (as we will see in the next section). Figure 8.2 symbolizes this ethically integrated or "embedded" idea of socio-economic rationality, which includes the precedence of legitimacy over efficiency.

The horizontal dimension of this T-model of integrative economic rationality represents the essential problem of a rational societal order of free and equal citizens, whereas the vertical dimension represents the "pure" economic rationality (or efficiency) of "free markets." The first dimension of socio-economic rationality has systematic priority, because the good life and just coexistence of free citizens is an end in itself. However, as we have already seen, the efficient use of scarce resources and goods is only a means. There is no "efficiency" as such we have to determine for whom, and in regard to which of his/her life plans, something is to be used efficiently. A self-determined life script is not only the constitutive moment of free citizenship; it is also an indispensable moment of any rational economic activity. 
Thus, free citizenship is a universal precondition of a fair market economy, as well as the guiding principle of modern civil society. As a logical consequence, we have to plead for a two-level concept of liberalism: free citizens take priority over "free" markets. Therefore, market liberalism has to be embedded into a political or, more precisely, a republican concept of liberalism: its focus is on the res publica of the equal freedom and fair coexistence of all citizens.

\section{The republican spirit of true liberalism and the business ethos of responsible citizens}

Properly understood, freedom is, of course, not "natural liberty" (as usually seen by libertarians) but politically constituted freedom constituted by a universal set of inviolable civic rights laid down in the constitution of a free and democratic society and supported by citizens who have a corresponding civic mind. This is the basic insight of political liberalism according to John Rawls (1993). Its core is certainly the idea of the constitutional role of strong and equal civic rights as the central mode of social integration. In contrast, neoliberal doctrine regards the mutual exchange of advantages in the market as the central mode of social order, and the communitarians assume that the community spirit, i.e. the shared values of a specific cultural tradition, fulfills this constitutive role. While this is not the place for a thorough critique of these two pseudo-alternatives (see Ulrich 2008: 276ff.), political liberalism appears to be the best option.

The Rawlsian conception of justice in a liberal society is, however, not strong enough to tackle the socio-economic challenges that we face today. This concept lacks a thorough and all-encompassing delimitation from market liberalism, as Rawls does not fully consider the structural partiality of the free market (Ulrich 2008: 131ff., 239), which is incompatible with his supposition that the basic political order of a liberal society has to be neutral with regard to different concepts of a good life (Rawls 1993: 190ff.). Consequently, Rawls does not reflect enough on the importance of social and economic citizenship rights as a precondition of a well-ordered society. The established basic personality and political citizenship rights are not good enough under the competitive constraints of our time. In line with Thomas Marshall's classical distinction (1963), we need a third group of socio-economic citizenship rights as the basis of real freedom 
for all (Van Parijs 1995). This completion of civic rights could be a crucial point in granting or saving the principles of a humane society in our current "economic life." Let us examine the indispensable motivational basis of such an undertaking before returning, in the next section, to the institutional side of the problem.

Both political liberalism (in the Rawlsian sense) and radical marketbased neoliberalism (libertarianism) hardly provide any motives for individuals to be interested in a just and unified, or at least a "decent," society (in the sense of Margalit 1996), rather than in the sole pursuit of private interests. However, it is impossible to establish a better societal order without citizens who really want it, who understand it, and who are able to recognize their resulting self-responsibility as well as their co-responsibility for the res publica. In this regard, the tradition of political republicanism has always been a decisive moment of civil society, as Pocock (1975) and many other political philosophers have demonstrated. What is important, however, is to integrate the republican spirit within a liberal order - which means not sacrificing the constitutive role of civic rights - in order to synthesize a republican liberalism. ${ }^{2}$ The core idea of republican liberalism - in the republican tradition - is that civic virtue is essential but, according to political liberalism and contrary to classical republicanism, it should focus on nothing but the general and real freedom of the citizens. This republican-liberal ethos deeply affects the selfimage of the citizens: They desire to live as free citizens among others, not against them. Consequently, they participate mentally and politically in the public matters of a well-ordered society and integrate their private interests into this political self-understanding. That is why they are, in principle, willing to bind themselves to the ethical principles of harmoniously living together in a free and fair society.

When applied to business life, this civic spirit takes the form of a republican business ethos: even as economic agents, the citizens are ready to integrate their "acquisitive intentions" (or "capitalist spirit" as explained by Max Weber 1930) into their civic sense and be coresponsible for a well-ordered res publica of truly free citizens. As a result, they are interested in personal success or profit only as far as

2 See Ulrich 2008: 278ff. (first German edition, 1997) and (independently) Dagger 1997, who does not, however, consider the socio-economic side of the concept. 
they, as citizens, can accept this as ethically and politically legitimate. Business integrity therefore means quite literally that a business person is not willing to behave as an economic agent only - by separating private financial and business interests from his/her civic identity. The same applies to a company or corporation. Accordingly, corporate citizenship would mean significantly more than "corporate giving," after making the greatest possible profit with an unquestioned business model. It would, furthermore, mean more than community involvement separated as far as possible from the inherent normative content of the business model itself. Rather, corporate citizenship involves a basic integration of the declared principles of business integrity into one's own business model along with a republican coresponsibility for public concerns: especially for a "civilizing" regulatory framework of the markets - including all the implications for a company's own business policy.

The contrast is obvious between this integrated republicanliberal identity, on the one hand, and "possessive individualism" (Macpherson 1962), as conceived by Thomas Hobbes, on the other. The latter is nothing other than the concept of economic man behind pure market liberalism. The primary task of all concerned with the socio-economic and political foundations of a truly liberal society (instead of a liberal economy only) is to support the project of such a republican liberalism by integrating the institutional concept of political liberalism with the civic spirit of economic agents who are ready to understand and to acknowledge their societal responsibilities.

One of the central concerns of citizens with a republican business ethos certainly focuses on social and economic citizenship rights as a means of "civilizing" the market economy. Civic rights are, after all, understood as the constitutive mode of social integration in a well-ordered society of free and equal citizens. The systematic consequence is that citizens will sympathize with and become actively involved in a rights-based approach to a humane socio-economic order, instead of a needs-based approach to "humanistic economics" (Lutz and Lux 1988).

\section{The core of a civilized market economy: rights and responsibilities of economic citizenship}

The self-determined conduct of an individual life is central to citizenship status; and this status has to be guaranteed for all citizens 
regardless of their socio-economic conditions. Lord Dahrendorf made the following point: "Citizenship is a non-economic concept. It defines people's standing independent of the relative value attached to their contribution to the economic process. The elements of citizenship are thus unconditional" (Dahrendorf 1994: 13). It is precisely the function of strong economic and social citizenship rights to guarantee this order of precedence.

The fundamental consequence is an emancipatory conception of social or welfare policies, instead of an only compensatory one. More specifically: a social state that ex post compensates individuals who are not in a situation to compete and assert themselves in the market as a result of a lack of real freedom is not enough. In the republican liberalism perspective an ex ante approach is essential: citizens who are really free can help themselves and do not need "social welfare," except in circumstances of heavy blows of fate. Hence, the social progress of a civil society should not manifest itself in the growth of compensating social transfers, but in the enlargement of universal economic citizenship rights that give all citizens a fair chance to live a self-determined life. In brief: social progress is first a question of civic rights, not of money.

At this point, we detect the inherent social demand of a truly liberal society. Or to put it in a programmatic formula: a more emancipatory socio-economic citizenship status is the best way toward less need for compensatory social welfare. The old debate on social welfare policy (in the sense of compensatory social transfers) can and should be replaced with a debate on the socio-economic preconditions of universal and real civic freedom.

Republican liberalism is not directed against open and competitive markets. The contrary is true: the social integration of everybody, regardless of their success or failure in their economic life, should be regarded as the legitimate precondition for market pressure on people who need to earn their living in the (labor) market. The Danish concept of flexicurity - i.e. flexible labor markets within social security - demonstrates that a clear vertical order and combination of social integration and economic competition may be advantageous on both levels. Competitive markets can be a means in service of the common good, which increases when the people's citizenship status, in its full meaning of inviolable personal, political, and socioeconomic rights, is guaranteed. Consequently, first the markets have 
to be literally "civilized" by new economic citizenship rights and then the intensification of market competition will be both legitimate and life-serving.

The importance of this from civil society's point is clear. For the sake of the greatest possible real freedom for all citizens, "civilizing" the market economy is as vital as civilizing the state. Liberals of all schools have always postulated civilizing the state, but some of them are still blind with regard to markets. Now, a civilized market economy has to be understood as regulated by the civic rule of law as well. Inherent market necessities are no longer an accepted reason for limiting the real freedom and equal opportunities of citizens and the justice of the rules of the game. The opposite priority is actually crucial.

Concretizing economic citizenship rights in the different dimensions of a "civilized" economic life is obviously an epochal project that has to be tackled democratically by mature citizens. Distributing economic and social rights, and no longer merely material goods, is essential for the emancipatory goal. Economic citizenship rights clearly aim at the material improvement of the conditions of disadvantaged persons. However, they do this indirectly, primarily by strengthening the chances of self-determination and self-assertion, and thus civil status, in "economic life." Access to education and knowhow, capital, and credit - especially micro credits for the poor (Yunus 1999) - are the prerequisites of entrepreneurship for everyone; they therefore deserve the status of basic rights that expand the options of autonomous economic activity. Individual and collective rights to information, hearing, and participation, at least in decisions regarding jobs and working conditions, are also important for citizens working as employees.

While these economic activity rights help guarantee the status of full citizens within the market economy, a second dimension of economic civil rights will be increasingly vital in future. This second dimension aims at a fair chance for the partial emancipation of all citizens from the pressure of competing as "entrepreneurs" of (nothing but) their labor power at almost any price in the market. This is not a contradiction. Rather, a balance of integration in the working life and emancipation from the constraints of the "free" market corresponds to the very normal balance sought by free citizens between autonomy (in the sense of inviolable privacy) and social integration (in the sense 


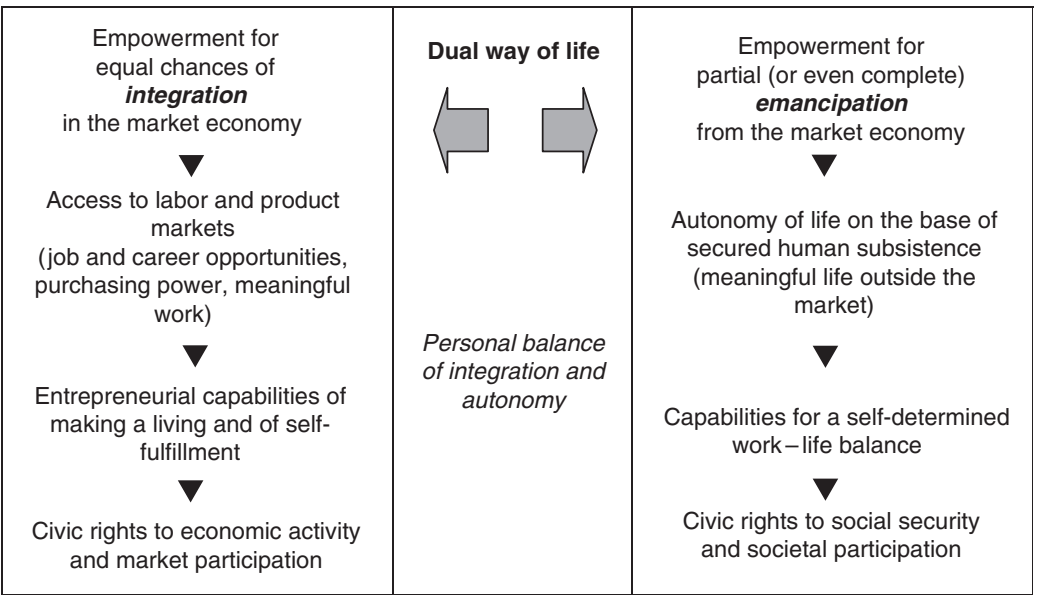

Figure 8.3 The dual empowerment function of (socio-) economic citizenship rights

of full participation in the res publica). We have probably not yet fully understood that this is also the prerequisite of a truly free "economic life." For the sake of this balance, the rights to economic activity need the complement of the emancipatory rights to social participation and protection (Figure 8.3).

The social rights of protection and participation are now understood as rights that partly liberate people from the "merciless" dependence on their success at self-assertion in the market. These rights grant a reasonable possibility of a non-humiliating form of existence outside the normal working life to those who, for whatever reasons, cannot or will not become integrated into the market. "Nonhumiliating" means being spared the stigmatization as failures and "welfare cases" and not being subjected to "special treatment" as a social problem group but, rather, claiming a universal, normal civil right without having to demonstrate a special justification or need. Thus, the universal character of social citizenship rights is essential in the emancipatory perspective of real civic freedom. In the long term, this might be reflected in the goal of an unconditional basic income for all citizens as the liberal Belgian social philosopher Philippe Van Parijs (1995) convincingly explained.

Such approaches to a fully developed civil society demonstrate how meaningful socio-economic progress is still possible in our 
hyper-dynamic, late-industrial society, which is fixed on endlessly increasing productivity and growth and rather disoriented with regard to the practical meaning of the whole. These integrated approaches reveal that all the countries of the world, even the advanced OECD countries, are still civilisatory "developing countries." These ideas can also be corroborated with recent findings on the global development problematic. Without money, nothing happens in development policy; however, money alone does not promote good socio-economic development. The empowerment of people for both integration into and partial emancipation from the market is essential if we regard the enlargement of real freedom for all citizens as the essence of human development. This is precisely why Amartya Sen (1999: 87) regards poverty and underdevelopment as expressions of a "capability deprivation," which is the lack of "substantive freedoms he or she enjoys to lead the kind of life he or she has reason to value."

However, as discussed above, human and civic development imply the republican ethos of responsible and reasonable citizens. Such a civic ethic is based on the normative logic of human interaction and substantiated in mutual respect and solidarity. Hence, the flipside of all citizen rights is the citizen's shared responsibility for the res publica of a civilized socio-economic order and all able citizens' fair contribution to social cooperation. Both guaranteed economic citizenship rights and responsibilities are, of course, essential subject matters of public deliberation by mature citizens. Responsibility might include fair tax paying and/or accepting a (lifetime's) minimum workload (White 2003: 202ff.). However, it seems to be important for a liberal society that such moral obligations do not become preconditions for the recognition of socio-economic citizenship rights, since this would simply undermine the emancipatory sense of rights like an unconditional basic income for all citizens (van der Veen 1997; Van Parijs 1997).

\section{Conclusion}

In conclusion, there are three core elements of a republican-liberal political order (Ulrich 2008: 242): first, as a motivational base, an appropriate civic virtue with its resulting republican business ethos; second, as the constitutive order principle, fully established civic rights including (instead of excluding, as to date) the socio-economic 
preconditions of a really free and decent living; and third, as an economic-ethical consequence, a truly civilized market economy. Civilizing the market economy is an idea as constitutive of a humane society as that of the civilizing of the state. It is time to acknowledge that the traditional, "purely" economic recipes (as represented by neoliberal doctrine) are no longer sufficient to meet today's socioeconomic challenges. The core problem, at least of advanced countries, is not a lack of productivity and competitiveness but, on the contrary, an inconvenient awareness and handling of the societal consequences of a highly productive market economy. "It's not the economy, stupid - it's society!" The conception of a fully developed civil society, including a truly civilized market economy, might open new vistas of human development all over the world.

\section{References}

Dagger, R. 1997. Civic Virtues: Rights, Citizenship, and Republican Liberalism. New York and Oxford: Oxford University Press.

Dahrendorf, R. 1994. "The Changing Quality of Citizenship," in B. Van Steenbergen (ed.), The Condition of Citizenship. London: Sage, pp. $10-19$.

Lutz, M. A. and Lux, K. 1988. Humanistic Economics: The New Challenge. New York: Bootstrap.

Macpherson, C. B. 1962: The Political Theory of Possessive Individualism. Oxford: Clarendon Press.

Margalit, A. 1996. The Decent Society. Cambridge, MA: Harvard University Press.

Marshall, T. M. 1963. "Citizenship and Social Class," in Sociology at the Crossroads and Other Essays. London: Heinemann, pp. 67-127.

Pocock, J.G.A. 1975. The Machiavellian Moment: Florentine Political Thought and the Atlantic Republican Tradition. Princeton, NJ: Princeton University Press.

Rawls, J. 1993. Political Liberalism. New York: Columbia University Press. Sen, A. 1999. Development as Freedom. Oxford: Oxford University Press. Tugendhat, E. 1994. Vorlesungen über Ethik. Frankfurt: Suhrkamp.

Ulrich, P. 2003. "Ethics and Economics," in L. Zsolnai (ed.), Ethics in the Economy: Handbook of Business Ethics (second edition). Berne and Oxford: Peter Lang, pp. 9-37.

2008. Integrative Economic Ethics: Foundations of a Civilized Market Economy. Cambridge: Cambridge University Press [first published in German language, 1997, fourth edition 2008]. 
van der Veen, R. J. 1997. "Real Freedom versus Reciprocity: Competing Views on the Justice of Unconditional Basic Income," Political Studies XLV: 140-63.

Van Parijs, P. 1995. Real Freedom for All: What (If Anything) Can Justify Capitalism? Oxford: Oxford University Press.

1997. "Reciprocity and the Justification of an Unconditional Basic Income. Reply to Stuart White," Political Studies XLV: 327-30.

Weber, M. 1930. The Protestant Ethic and the Spirit of Capitalism, trans. T. Parsons. London: Unwin Hyman.

White, S. 2003. The Civic Minimum: On the Rights and Obligations of Economic Citizenship. New York and Oxford: Oxford University Press.

Yunus, M. 1999. Banker to the Poor: Micro-Lending and the Battle against World Poverty. New York: Public Affairs. 


\section{Humanism in Business}

Edited by Heiko Spitzeck

Universität St Gallen, Switzerland

Michael Pirson

Harvard University, Massachusetts

Wolfgang Amann

Universität St Gallen, Switzerland

Shiban Khan

Universität St Gallen, Switzerland

and Ernst von Kimakowitz

Universität St Gallen, Switzerland

What is the purpose of our economic system? What would a more life-serving economy look like? There are many books about business and society, yet very few of them question the primacy of GDP growth, profit maximization and individual utility maximization. Even developments with a humanistic touch like stakeholder participation, corporate social responsibility or corporate philanthropy serve the same goal: to foster long-term growth and profitability. Humanism in Business questions these assumptions and investigates the possibility of creating a human-centered, value-oriented society based on humanistic principles. An international team of academics and practitioners present philosophical, spiritual, economic, psychological and organizational arguments that show how humanism can be used to understand, and possibly transform, business at three different levels: the systems level, the organizational level and the individual level. This groundbreaking book will be of interest to academics, practitioners and policymakers concerned with business ethics and the relationship between business and society.

\section{Contents}

List of figures; List of tables; List of editors and contributors; HUMANET: HUmanistic MAnagement Research NETwork: paving the way towards a life-serving economy; Introduction; Part I. Philosophic-Historical Grounding of Humanism: 1. Philosophical grounds of Humanism in economics; 2. The Humanist tradition; 3. Humanism and culture: balancing particularity and universalism among the world's religions; 4 . A requisite journey: from business ethics to economic philosophy; 5 . The global economy from a moral point of view; 6 . The implications of Humanism for business studies; 7 . Current trends in Humanism and business; Part II. Towards an Integration of Humanism and Business on a Systems Level: 8 . Towards a civilized market economy: economic citizenship rights and responsibilities in service of a humane society; 9 . Development as freedom - individual freedom as a social commitment; 10 . On corporate responsibility for human rights; 11 . The value shift: merging social and financial imperatives; 12 . The ugly side of capitalism: what the young generation needs to combat; Part III. Humanistic Management: 13. Democratizing the corporation; 14 . Social entrepreneurship - a blueprint for humane organizations?; 15. Humanism at work: crucial organizational cultures and leadership principles; 16. Positive organizational scholarship: embodying a humanistic perspective of business; 17 . Corporate sustainability as an indicator for more humanism in business? A view beyond the usual hype in Europe; 18. Changing direction - corporations as ambassadors of the environment?; Part IV. The Individual as a Change Agent for a Humane

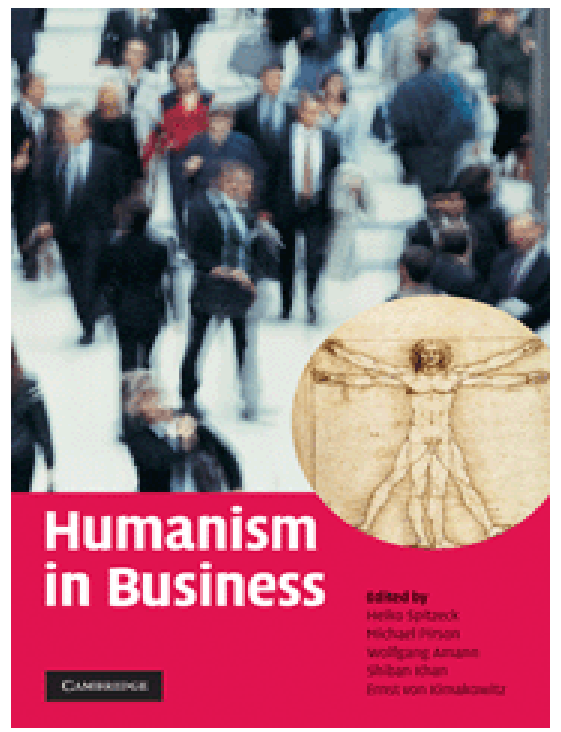




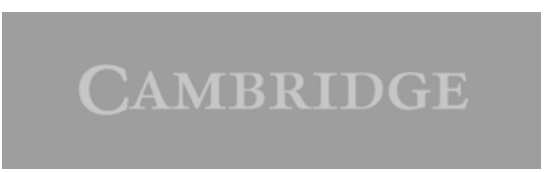

Business Society: 19. Ethical codes at work; 20. The daunting challenges of globalization and the power of individuals in cross-stakeholder networks for a humanistic face of globalization; 21. The leader as responsible change agent: promoting Humanism in and beyond business; 22 . Quiet leadership - a way to sustainable positive change; 23 . Everyone a changemaker: social entrepreneurship's ultimate goal; 24 . Social business entrepreneurs are the solution; 25 . Concluding observations; Index.

February $2009228 \times 152 \mathrm{~mm}$ 470pp 4 tables

Original price Discount price

$\begin{array}{llll}\text { Hardback } & f 60.00 & £ 48.00 & 978-0-521-89893-5 \\ \text { Paperback } & £ 23.99 & f 19.19 & 978-0-521-72762-4\end{array}$




\section{$20 \%$ discount order form}

Please return this form to:

HSS Marketing, Cambridge University Press, FREEPOST CB27, The Edinburgh Building, Cambridge CB2 1BR, UK. (no stamp needed)

To obtain your discount, please order by 1 October 2009

\section{Humanism in Business}

\section{Heiko Spitzeck, Michael Pirson Et Al.}

Please send me copies of 9780521898935

Please send me copies of 9780521727624

$\begin{array}{llll} & \text { Original price } & \text { Discount price } & \text { Total } \\ \text { Hardback } & f 60.00 & f 48.00 & f \\ \text { Paperback } & f 23.99 & f 19.19 & f\end{array}$

*VAT charges for European Community residents only $f$

Postage and packing (standard charge) $\mathrm{f} \quad 3.50$

Airmail ( $₫ 3.50$ extra per book) $f$

Total $f$

Name

Email

Address

Please allow 21 days for delivery in the UK

Postcode

Country

I enclose a sterling cheque for $f$ payable to Cambridge University Press and drawn against a UK bank

Card Number

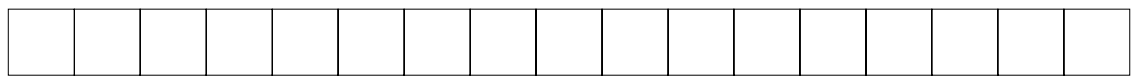

Expiry Date

Signature

Name of Cardholder

Cardholder's account address (if different from delivery address)

Postcode

Telephone/Fax ordering

Call $+44(0) 1223326050$

or fax $+44(0) 1223326111$ to order any

Cambridge book on your credit card. See

also www.cambridge.org

N.B. c. prices may change without notice

For information about our privacy and data protection policy, please visit uk.cambridge. org/privacy or email mlist@cambridge.org

\section{Country}

*Value Added Tax charge for European Union residents.

If you live in the European Union in one of the following member states

(Belgium, France, Germany, Ireland, Italy, Portugal, Spain or Sweden) and are not registered for VAT we are required to charge VAT at the rate applicable in your country of residence. If you live in any other member state in the EU and are not registered for VAT you will be charged VAT at the UK rate. Please add VAT for the full value of the order, including postage charges. Please note that disks, videos and cassettes are subject to VAT throughout the EU, including the UK. If you are registered for VAT please supply your registration number below and leave the VAT payment box blank. The Cambridge University Press VAT number is: GB 823847609 